\title{
Autolysis of Clown Featherback (Chitala ornata) Muscle
}

\author{
Chompunutch Thiabmak ${ }^{1}$, Chodsana Sriket ${ }^{2}$, Suthasinee Yarnpakdee ${ }^{3}$, \\ Siriporn Riebroy $\mathrm{Kim}^{4}$, and Sitthipong Nalinanon ${ }^{1^{*}}$ \\ ${ }^{I}$ Faculty of Agro-Industry, King Mongkut's Institute of Technology Ladkrabang, Bangkok \\ 10520, Thailand \\ ${ }^{2}$ Program in Food Science and Technology, Faculty of Agriculture, Ubon Ratchathani \\ Rajabhat University, Ubon Ratchathani 34000, Thailand \\ ${ }^{3}$ Division of Marine Product Technology, Faculty of Agro-Industry, Chiang Mai University, \\ Chiang Mai 50100, Thailand \\ ${ }^{4}$ Food and Nutrition Program, Faculty of Agriculture, Kasetsart University, Bangkok 10900, \\ Thailand \\ *Corresponding author. E-mail: sitthipong.na@kmitl.ac.th \\ https://doi.org/10.12982/CMUJNS.2019.0007
}

Received: July 16, 2018

Revised: September 8, 2018

Accepted: September 18, 2018

\begin{abstract}
Clown featherback (Chitala ornata) is a freshwater fish important in the cuisine of Thailand and other Southeast Asian countries. It has a short marketable life due mainly to poor gelling characteristic even when stored in ice. This deterioration has been associated with muscle autolysis. The research was aimed to investigate the autolysis of clown featherback muscle (CFM). To test autolysis, mince from CFM was incubated in a temperature controlled water bath for $60 \mathrm{~min}$ at $5,10,20,30,40,50,60,65,70,75$ or $80^{\circ} \mathrm{C}$ at $\mathrm{pH}$ levels over the range of 2-11. The results showed that the highest autolytic activity was at $70^{\circ} \mathrm{C}$ and it occurred at $\mathrm{pH}$ levels of 4 and 7 , with $\mathrm{pH} 4$ showing the highest autolysis. CFM was incubated with its crude enzyme counterpart at the physiological pH (6.73) at both $4^{\circ} \mathrm{C}$ and $25^{\circ} \mathrm{C}$. Degradation of natural actomyosin showed that after incubation at either temperature myosin heavy chain was susceptible to hydrolysis indicating that autolysis of CFM took place even at low temperature as affected by its endogenous proteases. The effects of several protease inhibitors were tested and autolysis at the physiological pH (6.73) was strongly inhibited by $10 \mu M$ pepstatin A (20.3\% inhibition), which had significantly higher inhibitory activity $(P<0.05)$ among the protease inhibitors tested. This suggests that aspartic protease was the major proteinase in CFM.
\end{abstract}

Keywords: Clown featherback, Autolysis, Actomyosin, Degradation, Fish muscle 


\section{INTRODUCTION}

The clown featherback (Chitala ornata) is a freshwater fish, native to the Chao Phraya and Meklong rivers, which is of economic importance and is receiving increasing attention in the cuisine of Thailand and other Southeast Asian countries (Uk-katawewat, 2004; Department of Fisheries, 2017). They have silvery gray skin with a long knife-like laterally compressed body and a long anal fin, which gives them their common name (Uk-katawewat, 2004). They are up to 1 meter long and weigh up to $15 \mathrm{~kg}$ (Berra, 2001). In Thailand, it is the main fish used in the production of fried fish patty and fish ball due to its abundance, white color and high gel-forming ability. However, poor gelling characteristic was observed in the fish kept in ice for a long time, which associated with autolysis of fish muscle (Benjakul et al., 2003a).

Autolysis refers to self-digestion through the action of its own proteolytic enzymes. The endogenous proteases, as well as the softening of gel products, have been recognized to have a major role in the quality loss of fish flesh, which reduces their commercial value (Yarnpakdee et al., 2009). Endogenous proteases, especially heat-activated and heat-stable proteases were shown to play an essential role in surimi gel weakening (Benjakul et al., 2003a). Fish muscle proteinases can be classified as sarcoplasmic and myofibril associated proteinases based on extractability (Kinoshita et al., 1990; Toyohara et al., 1990). Sarcoplasmic proteinases can be removed, to some extent, during the washing process, while myofibril associated proteinases still remain in surimi, resulting in gel weakening (Morrissey et al., 1995; Benjakul et al., 1996; Benjakul et al., 2003a). During processing of surimi products, the occurrence of heatinduced degradation is a universal and severe problem. When the surimi is passing through the temperature zone of $40-60{ }^{\circ} \mathrm{C}$ to form a gel, its protein components, especially myosin heavy chain (MHC), can be degraded and the development of a three-dimensional gel network inhibited, eventually giving very low gel strength. The degree of autolysis is governed by the type of proteases and has been shown to vary with fish species, for example Pacific whiting (An et al., 1994), chum salmon (Saeki et al., 1995) and arrowtooth flounder (Visessanguan et al., 2003). In those cases autolysis was caused by cathepsin L as a typical cysteine protease, while serine proteases were found to be responsible for textural breakdown of threadfin bream (Toyohara and Shimizu, 1988) and oval-filefish (Toyohara et al, 1990). Ohkubo et al. (2004) reported that a muscle soluble serine protease (MSSP) purified from the soluble fraction of lizard fish (Saurida undosquamis) muscle could degrade myofibrillar proteins while a collagenolytic serine proteinase (CSP) purified from red sea bream (Pagrus major) skeletal muscle might be involved in the softening of fish muscle, during the post-mortem stage, by degrading MHC (Wu et al., 2010). Moreover, Benjakul et al. (2003b) reported that the autolysis of lizardfish caused by myofibril-associated proteinases were both cysteine and serine proteinases. The degradation of fish muscle caused by endogenous proteases including serine and cysteine-type proteases was reported by Sriket (2014). Although the autolysis of fish muscle is governed by the type of protease, autolysis characteristics of different proteases are not similar. Yarnpakdee et al. (2009) reported that goatfish (Mulloidichthys martinicus) gel softening was caused by cysteine proteinase with maximum autolytic activity at $60{ }^{\circ} \mathrm{C}$. Benjakul et al. (2003b) reported that autolysis in lizardfish (Saurida tumbil) mince caused by cysteine proteinase with maximum proteolytic activity at $65^{\circ} \mathrm{C}$ whereas in arrowtooth flounder the maximum autolytic activity was at $50-60{ }^{\circ} \mathrm{C}$ (Greene and Babbitt, 1990; Visessanguan et al., 2001). The study on post-mortem degradation of Atlantic cod muscle showed that cysteine and aspartic proteinases 
are responsible for its MHC degradation (Wang et al., 2011). However, no information on the autholysis of muscle and mince of clown feather has been reported. Therefore, the objective of this work was to study on the autolysis of clown featherback muscle and its endogenous proteases characteristics.

\section{MATERIALS AND METHODS}

\section{Preparation of fish muscle}

Clown featherback fish, each weighing approximately $1.5 \mathrm{~kg}$, were purchased from Huatakae fresh market. The fish had been caught the same day and transported on ice to the market. Then they were purchased and kept in ice with a fish/ice ratio 1:2 (w/v) and transported to Faculty of Agro-Industry, King Mongkut's Institute of Technology Ladkrabang, Thailand within $30 \mathrm{~min}$. Fish were then headed, gutted and washed with tap water. The flesh was separated manually from skin and bone, minced and kept in polyethylene bags and stored in ice and used within $12 \mathrm{~h}$.

\section{Effect of temperature on autolysis}

Mince ( $3 \mathrm{~g}$ ) was mixed with $9 \mathrm{~mL}$ of physiological $\mathrm{pH}$ buffer (6.73) and incubated at different temperatures $\left(5,10,20,30,40,50,60,65,70,75\right.$ or $\left.80{ }^{\circ} \mathrm{C}\right)$ in a temperaturecontrolled water bath for $60 \mathrm{~min}$. The autolytic reaction was terminated by addition of 27 $\mathrm{mL}$ of cold $5 \%$ trichloroacetic acid (TCA) $(\mathrm{w} / \mathrm{v})$. The mixture was homogenized for $1 \mathrm{~min}$ at $11,000 \mathrm{rpm}$. The homogenate was centrifuged at 7,500 $\mathrm{g}$ for $10 \mathrm{~min}$ using a microcentrifuge. TCA-soluble peptide content in the supernatant was determined by the Lowry method (Lowry et al., 1951) using L-tyrosine as a standard and was expressed as $\mu \mathrm{mol}$ tyrosine/g sample.

To determine the autolytic pattern of fish muscle, another $3 \mathrm{~g}$ sample was incubated at different temperatures as previously described for $60 \mathrm{~min}$ and then mixed with $27 \mathrm{~mL}$ of $5 \%$ sodium dodecyl sulfate (SDS) at $85^{\circ} \mathrm{C}$ to terminate the autolytic reaction, followed by homogenization at $11,000 \mathrm{rpm}$ for $1 \mathrm{~min}$ and incubation at $85^{\circ} \mathrm{C}$ for $60 \mathrm{~min}$ to solubilize the sample. To remove undissolved debris, the mixture was centrifuged at 7,500 g for $10 \mathrm{~min}$. The supernatant was subjected to sodium dodecyl sulphate polyacrylamide gel electrophoresis (SDS-PAGE) analysis.

\section{Effect of pH on autolysis}

Mince $(3 \mathrm{~g})$ was mixed with $9 \mathrm{~mL}$ of different buffers having various $\mathrm{pH}$ levels. Those included 0.2 M McIlvaines' buffer (0.2 M sodium-phosphate and 0.1 M Sodium-citrate) for $\mathrm{pH}$ 2.0-7.0 and phosphate-borate buffer $\left(0.1 \mathrm{M} \mathrm{Na}_{2} \mathrm{HPO}_{4}-0.05 \mathrm{M} \mathrm{Na}_{2} \mathrm{~B}_{4} \mathrm{O}_{7}\right)$ for $\mathrm{pH}$ 8.0-11.0. The homogenate was incubated at $70{ }^{\circ} \mathrm{C}$ (optimal temperature). Autolysis was terminated after $60 \mathrm{~min}$ of incubation by the addition of $27 \mathrm{~mL}$ of cold 5\% TCA or 5\% SDS solution $\left(85^{\circ} \mathrm{C}\right)$ as previously described. TCA-soluble peptide content and SDS-PAGE protein patterns were determined, respectively.

\section{Effect of various protease inhibitors on autolysis of mince}

Mince $(0.5 \mathrm{~g})$ was homogenized (11,000 rpm for $1 \mathrm{~min})$ with $1.5 \mathrm{~mL}$ of the physiological $\mathrm{pH}$ buffer (6.73). The homogenate was mixed with $2 \mathrm{~mL}$ of protease inhibitor solution to obtain the final designated concentration: $2 \mathrm{mM}$ EDTA, $0.01 \mathrm{mM}$ soybean trypsin inhibitor (SBTI), 
$0.01 \mathrm{mM} \mathrm{E}-64$ and $1 \mu \mathrm{M}$ and $10 \mu \mathrm{M}$ pepstatin A. The mixtures were allowed to stand in ice for $2 \mathrm{~h}$, followed by incubation at the room temperature for $3 \mathrm{~h}$. Autolysis was terminated by addition of $2 \mathrm{~mL}$ of either $10 \%$ TCA or $10 \%$ SDS solution $\left(85^{\circ} \mathrm{C}\right)$. TCA-soluble peptide content and SDS-PAGE protein patterns were then determined. The control used deionized water instead of protease inhibitor solution.

\section{Effect of crude proteolytic enzyme on the degradation of natural actomyosin extracted from CFM}

Preparation of crude proteolytic enzyme from CFM. Crude proteolytic enzyme from fish muscle was prepared according to the method of Liu et al. (2008) with slight modifications. All stages were carried out at $4{ }^{\circ} \mathrm{C}$, mince $(50 \mathrm{~g})$ was homogenized at 11,000 rpm for $5 \mathrm{~min}$ in a homogenizer with 10 volumes (v/w) of McIlvaines' buffer, $\mathrm{pH}$ 6.73. The homogenate was then centrifuged at $11,000 \mathrm{~g}$ for $30 \mathrm{~min}$. The supernatant was collected and referred to as "crude proteolytic enzyme; CPE". Proteolytic activity of CPE was determined using hemoglobin as a substrate according to the method of Nalinanon et al. (2010) with some modifications.

Preparation on natural actomyosin (NAM) from CFM. NAM was extracted from clown featherback according to the method of Ding et al. (2012) with some modifications. Briefly, clown featherback mince $(100 \mathrm{~g})$ was rinsed with $400 \mathrm{~mL}$ of low salt phosphate buffer $\left(0.05 \mathrm{M} \mathrm{KCl}, 3.38 \mathrm{mM} \mathrm{Na}_{2} \mathrm{HPO}_{4}, 15.5 \mathrm{mM} \mathrm{NaH}_{2} \mathrm{PO}_{4}, \mathrm{pH} 7.5\right)$ to remove water-soluble protein, and the pellets were rinsed twice using the above buffer. Subsequently, the obtained pellets were extracted with $300 \mathrm{~mL}$ of high salt phosphate buffer $(0.45 \mathrm{M} \mathrm{KCl}, 3.38 \mathrm{mM}$ $\mathrm{Na}_{2} \mathrm{HPO}_{4}, 15.5 \mathrm{mM} \mathrm{NaH}_{2} \mathrm{PO}_{4}$, and $\mathrm{pH} 7.5$ ) for $20 \mathrm{~h}$ at $4{ }^{\circ} \mathrm{C}$. After centrifugation at $15,000 \mathrm{~g}$ for $10 \mathrm{~min}$, the supernatant was poured into $3 \mathrm{~L}$ of deionized water to precipitate NAM at $4{ }^{\circ} \mathrm{C}$. Clown featherback NAM was then collected by centrifugation at $22,000 \mathrm{~g}$ for $10 \mathrm{~min}$ at $4{ }^{\circ} \mathrm{C}$.

Degradation of NAM extracted from clown featherback muscle. To determine the degradation pattern, a NAM sample (3 g) was hydrolyzed with CPE from CFM at physiological $\mathrm{pH}(6.73)$ in a temperature controlled at 4 and $25{ }^{\circ} \mathrm{C}$ for $3 \mathrm{~h}$. The hydrolysates were mixed with $27 \mathrm{~mL}$ of $5 \% \mathrm{SDS}\left(85^{\circ} \mathrm{C}\right)$ to terminate the enzyme activity. The mixture was subjected to homogenization at $11,000 \mathrm{rpm}$ for $1 \mathrm{~min}$. The homogenate was then incubated at $85^{\circ} \mathrm{C}$ for $60 \mathrm{~min}$ to solubilize the sample. To remove undissolved debris, the mixture was centrifuged at 7,500 $\mathrm{g}$ for $10 \mathrm{~min}$. The supernatant was subjected to SDS-PAGE analysis.

\section{Sodium dodecyl sulphate polyacrylamide gel electrophoresis (SDS-PAGE)}

Protein patterns of mince were obtained by SDS-PAGE according to the method of Leammli (1970). SDS-solubilized samples with $15 \mu \mathrm{g}$ of protein per channel were loaded on to the polyacrylamide gel made of a $10 \%$ running gel and a $4 \%$ stacking gel and were subjected to electrophoresis at a constant current of $15 \mathrm{~mA}$ per gel, using a AE6450 unit (ATTO Corporation, Tokyo, Japan). After separation, the proteins were stained with $0.08 \%$ (w/v) Coomassie Brilliant Blue G-250 in 1.6\% (w/v) ortho-phosphoric acid and 8\% (w/v) ammonium sulphate and destained with $50 \%$ methanol (v/v) and $7.5 \%(\mathrm{v} / \mathrm{v})$ acetic acid, followed by $5 \%$ methanol (v/v) and 7.5\% (v/v) acetic acid. Gels were imaged using a CanoScan 
LiDE100 image scanner and band intensities were quantified with the domain digital analysis software, ImageJ 1.42q. The band intensity of MHC and actin in each sample was expressed as a percentage of that found in mince.

\section{Statistical analysis}

All experiments were carried out in triplicate. Data were subjected to Analysis of Variance (ANOVA) and mean comparisons were carried out using Duncan's multiple range test. SPSS statistic program (SPSS 11.0 for Windows, SPSS Inc., Chicago, IL, USA) was used for data analysis.

\section{RESULTS}

\section{Autolysis of CFM}

Effect of temperature. The autolytic degradation of clown featherback mince incubated at various temperatures was monitored and expressed in terms of TCA soluble peptide content (Figure 1). The temperature profile was analyzed at the physiological $\mathrm{pH}$ (6.73) of fish by $\mathrm{pH}$ adjustment. The maximal autolytic activity of clown featherback mince was observed at $70{ }^{\circ} \mathrm{C}$ as evidenced by the highest TCA-soluble peptide content. However, a decrease in autolytic activity was found when the temperature was above $70{ }^{\circ} \mathrm{C}$. Autolytic patterns of clown featherback mince are shown in Figure 2. The degradation was observed at $70^{\circ} \mathrm{C}$, as evidenced by the marked decrease in MHC band intensity when compared with that of the samples without incubation.

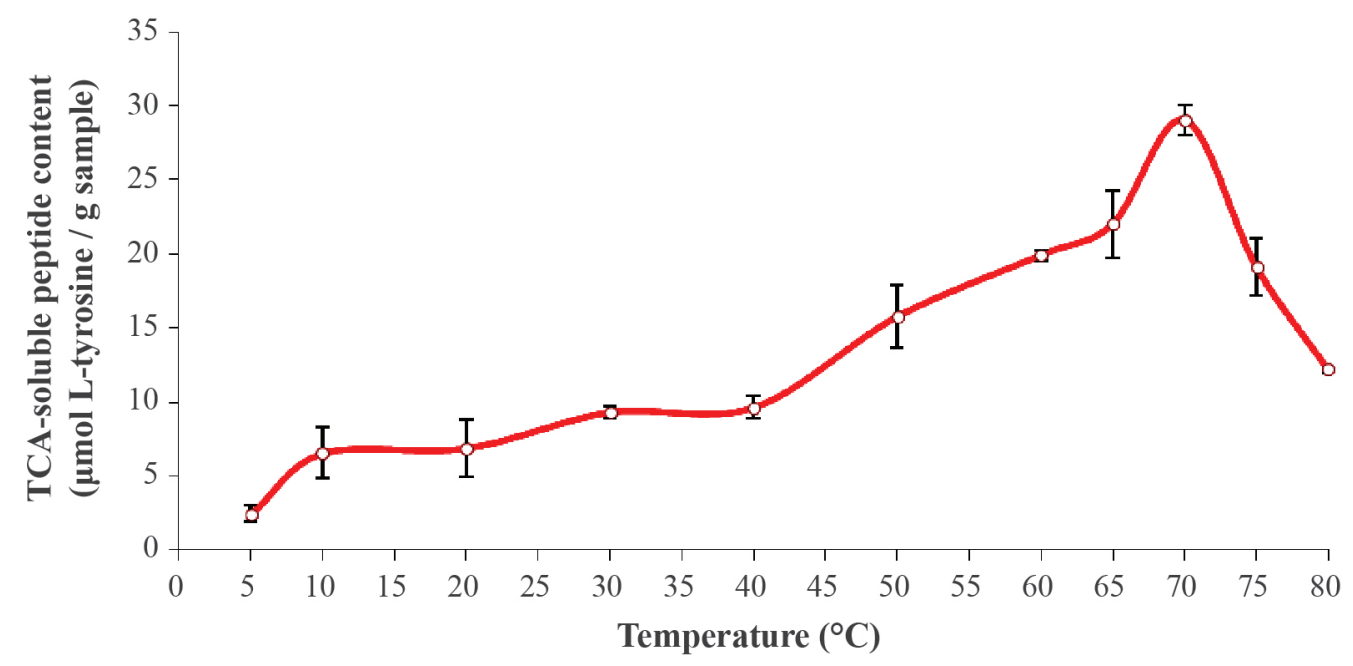

Figure 1. TCA-soluble peptide content from clown featherback mince incubated at various temperatures at physiological $\mathrm{pH}$ (6.73) for $60 \mathrm{~min}$. Bars represent the standard deviation from triplicate determinations. 


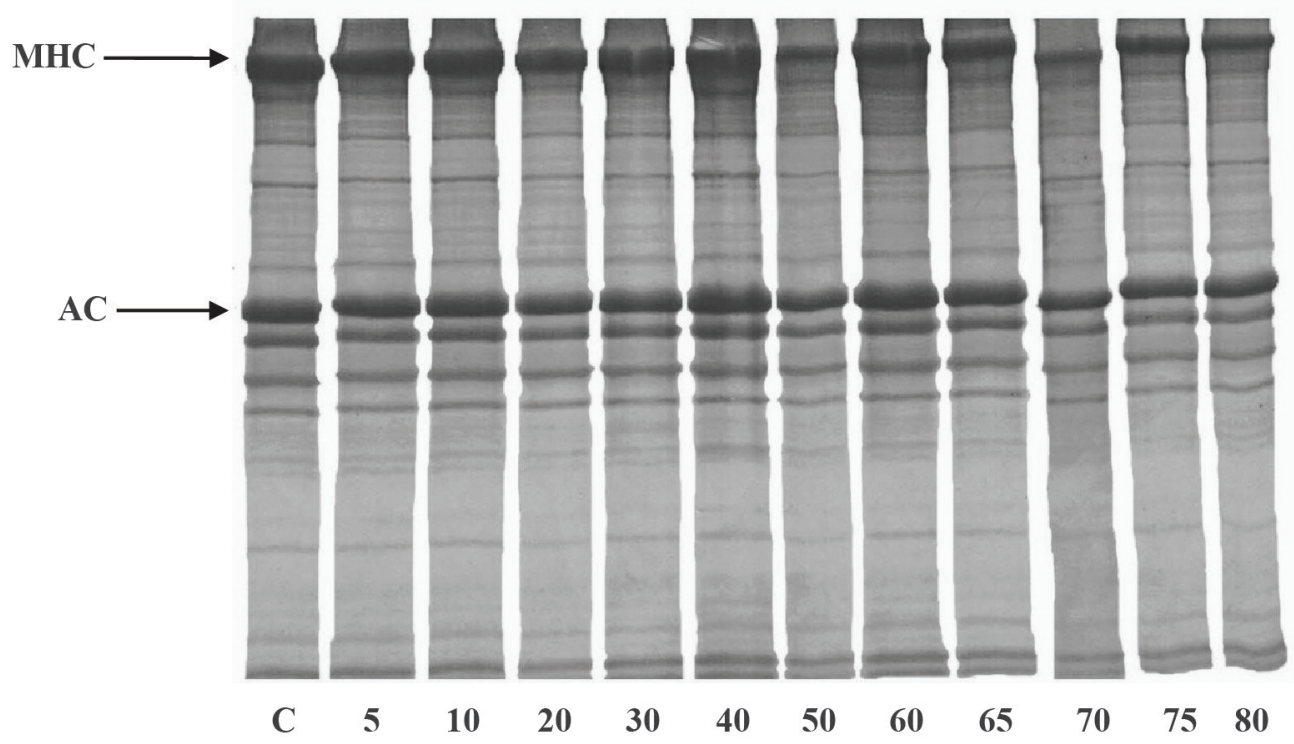

Figure 2. Autolytic patterns of clown featherback mince incubated at various temperatures at physiological $\mathrm{pH}$ (6.73) for $60 \mathrm{~min}$. C, MHC and AC denote clown featherback mince without incubation, myosin heavy chain and actin, respectively. Numbers designate incubation temperatures $\left({ }^{\circ} \mathrm{C}\right)$.

Effect of pH. The $\mathrm{pH}$ profiles for the autolysis of clown featherback mince conducted at the optimal temperature $\left(70^{\circ} \mathrm{C}\right)$ for $60 \mathrm{~min}$ are expressed in terms of TCA soluble peptide content (Figure 3). The major activity peak was found at $\mathrm{pH} 4$ and a smaller one at $\mathrm{pH} 7$, which represent proteolytic activity of acid and neutral proteases, respectively. The autolytic pattern of clown featherback mince at various $\mathrm{pH}$ levels determined by SDS-PAGE is shown in Figure 4. The highest degradation of MHC was observed at $\mathrm{pH} 4$ and 7 as shown by the lowest band intensity. This result was in agreement with the greater TCA-soluble peptide contents at acidic and natural $\mathrm{pH}$ levels. However, actin still remained after incubation in all treatments, even though lower band intensity was found in $\mathrm{pH} 4$ and 7. This might be due to the globular configuration and compact structure of actin, which could not facilitate enzyme hydrolysis. 


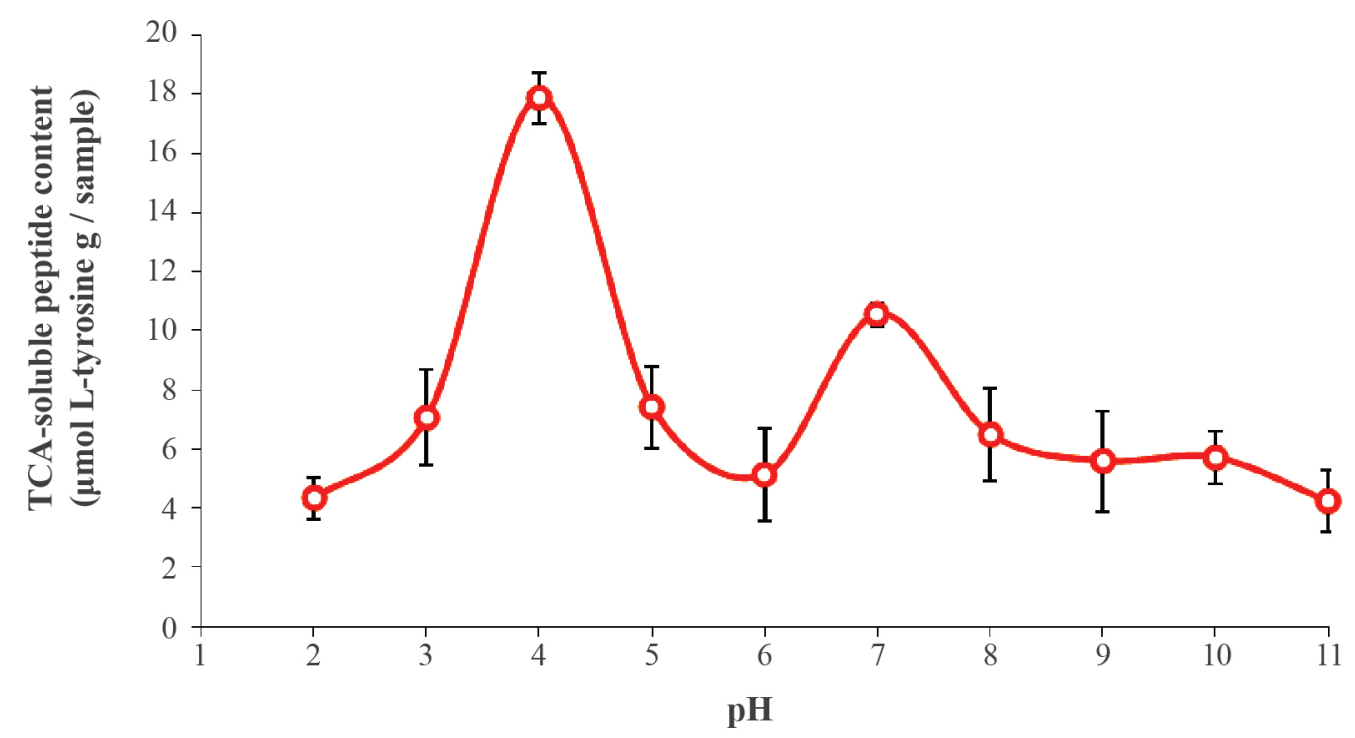

Figure 3. TCA-soluble peptide released from clown featherback mince incubated at various $\mathrm{pH}$ levels at $70{ }^{\circ} \mathrm{C}$ for $60 \mathrm{~min}$. Bars represent the standard deviation from triplicate determinations.

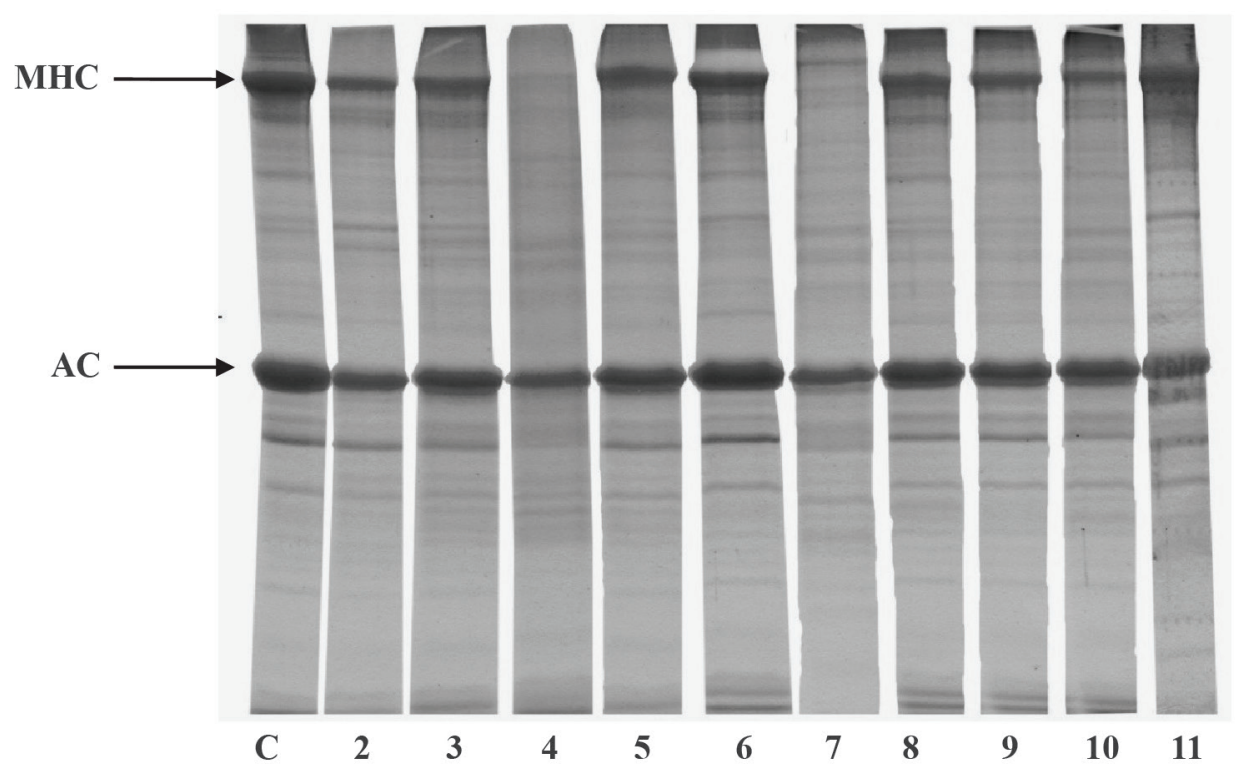

Figure 4. Autolytic patterns of clown featherback mince incubated at various pHs at $70{ }^{\circ} \mathrm{C}$ for $60 \mathrm{~min} . \mathrm{C}, \mathrm{MHC}$ and $\mathrm{AC}$ are clown featherback mince incubated at physiological $\mathrm{pH}$ (6.73), myosin heavy chain and actin, respectively. Numbers denote $\mathrm{pH}$ level of incubation. 


\section{Effect of protease inhibitors on autolysis}

The effect of various protease inhibitors on autolysis of clown featherback mince was conducted at physiological $\mathrm{pH}(6.73)$ and room temperature (approximately $25^{\circ} \mathrm{C}$ ) for $3 \mathrm{~h}$ as shown in Table 1. The result showed that the inhibitors, including soybean trypsin inhibitor (SBTI) (serine protease inhibitor), E-64 (cysteine protease inhibitor), EDTA (metallo proteinase inhibitor) and pepstatin A (aspartic protease inhibitor) all had effective low inhibitory activity in the range of about $10 \%$ to just over $20 \%$. Protein patterns of clown featherback mince as affected by various protease inhibitors were studied (Figure 5). There were no differentiated changes of protein degradation of each treatment. However, a slightly lower band intensity of $\mathrm{MHC}$ in treatments without addition of proteinase inhibitors was observed.

Table 1. Effect of various protease inhibitors on autolysis of clown featherback mince.*

\begin{tabular}{lccc}
\hline Inhibitors & Concentrations & $\begin{array}{c}\text { TCA-soluble peptide } \\
(\boldsymbol{\mu m o l} / \mathbf{g})\end{array}$ & \% Inhibition \\
\hline Control & - & $487.78 \pm 2.22$ & $0^{\text {ał }}$ \\
SBTI & $0.01 \mathrm{mM}$ & $436.84 \pm 4.24$ & $10.44 \pm 0.87 \mathrm{~b}$ \\
E-64 & $0.01 \mathrm{mM}$ & $419.11 \pm 3.46$ & $14.08 \pm 0.71 \mathrm{c}$ \\
EDTA & $2.00 \mathrm{mM}$ & $434.43 \pm 3.05$ & $10.94 \pm 0.63 \mathrm{~b}$ \\
Pepstatin A & $10.000 \mu \mathrm{M}$ & $388.76 \pm 4.87$ & $20.33 \pm 1.61 \mathrm{~d}$ \\
Pepstatin A & $1.00 \mu \mathrm{M}$ & $412.45 \pm 3.06$ & $15.44 \pm 2.06 \mathrm{c}$ \\
\hline
\end{tabular}

Note: 'Different superscript letters in the same column indicate significant differences $(P<0.05)$; ${ }^{*}$ Values are given as mean $\pm \mathrm{SD}$ from triplicate determinations.

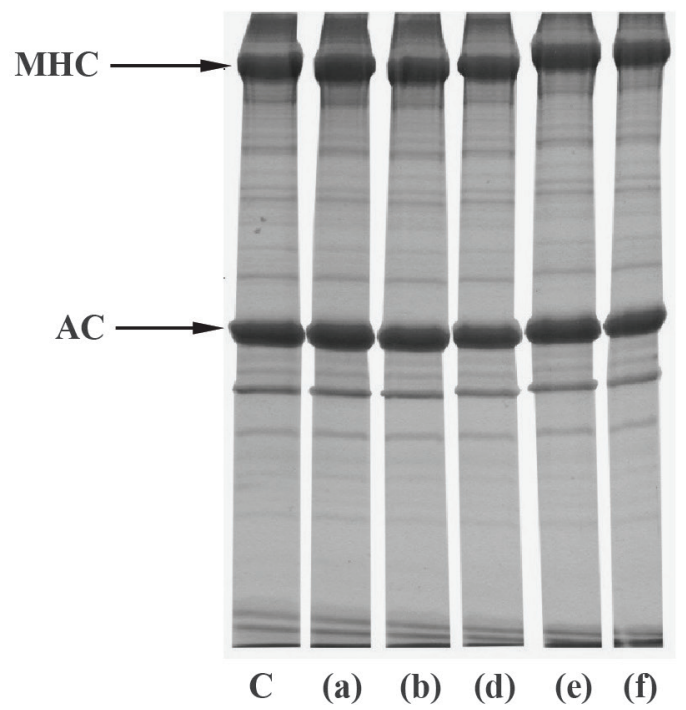

Figure 5. Autolytic patterns of clown featherback mince incubated with various inhibitors at room temperature at physiological $\mathrm{pH}(6.73)$ for $3 \mathrm{~h}$. C: clown featherback mince without inhibitor; (a) $2 \mathrm{mM}$ EDTA; (b) $0.01 \mathrm{mM}$ E-64; (d) $0.01 \mathrm{mM}$ SBTI; (e) $10 \mu \mathrm{M}$ pepstatin A; (f) $1 \mu \mathrm{M}$ pepstatin A. MHC and AC are myosin heavy chain and actin, respectively. 


\section{Degradation of NAM as affected by CPE from CFM}

The protein patterns of natural actomyosin (NAM) incubated with crude enzyme from $\mathrm{CFM}$ at $4{ }^{\circ} \mathrm{C}$ and $25^{\circ} \mathrm{C}$ for $3 \mathrm{~h}$ show that MHC and actin were major proteins in CFM (Figure 6). MHC and AC had molecular weights estimated from the mobilities in SDS-PAGE at about $214.0 \mathrm{kDa}$ and $44.2 \mathrm{kDa}$, respectively. The result also show that MHC had a lower intensity (87.4\% of that found in mince as quantified with ImageJ $1.42 \mathrm{q}$ program) after incubation with crude enzyme from CFM at $4^{\circ} \mathrm{C}$ and $25^{\circ} \mathrm{C}$, when compared with the control sample. Degradation bands were observed with molecular weights of 51.6, 40.4 and $29.9 \mathrm{kDa}$ for major degradation bands and other bands with molecular weights ranged from 50 to $75 \mathrm{kDa}$. However, no marked changes in actin band intensity were observed when the crude enzyme extract was added.

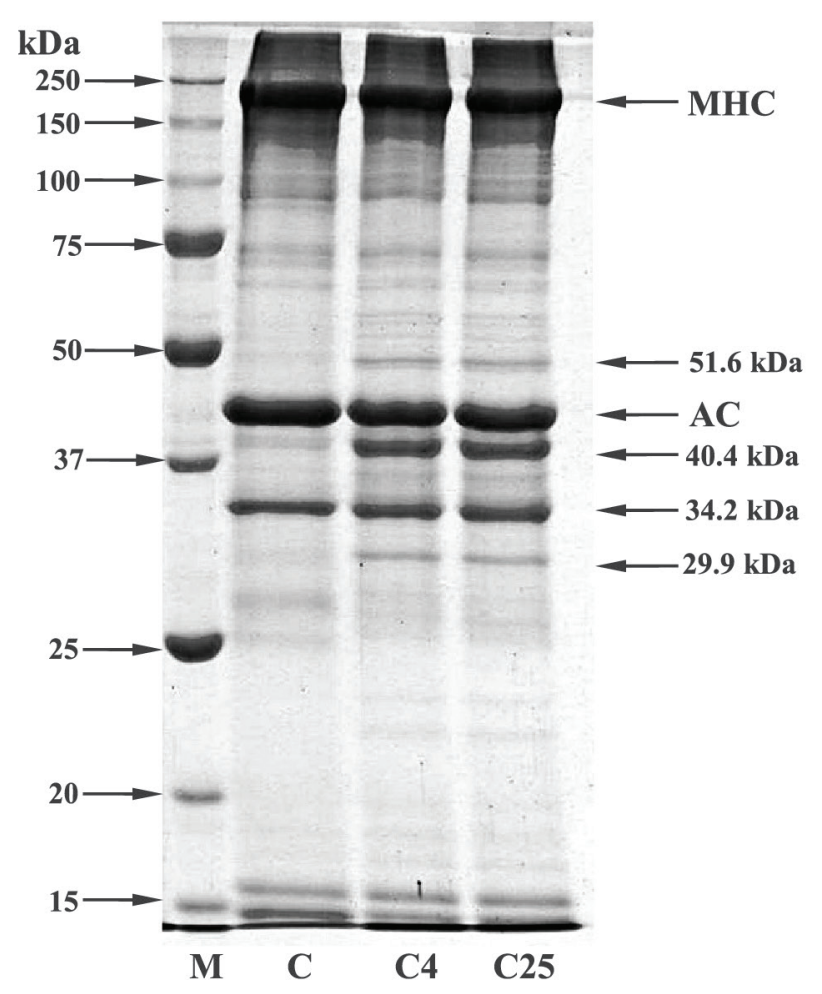

Figure 6. SDS-PAGE patterns of natural actomyosin (NAM) (C) extracted from clown featherback muscle (CFM) incubated with crude proteolytic enzyme (CPE) from $\mathrm{CFM}$ at $4{ }^{\circ} \mathrm{C}(\mathrm{C} 4)$ and $25^{\circ} \mathrm{C}(\mathrm{C} 25)$ at physiological $\mathrm{pH}$ (6.73) for $60 \mathrm{~min} . \mathrm{M}, \mathrm{MHC}$ and $\mathrm{AC}$ denote molecular mass markers, myosin heavy chain and actin, respectively. 


\section{DISCUSSION}

Surprisingly, the degradation of clown featherback mince noticeably occurred at high temperature $\left(70{ }^{\circ} \mathrm{C}\right)$. It was postulated that myofibrillar proteins were partially denatured, facilitating maximal hydrolysis by heat-activated endogenous proteinases. However, a decrease in autolytic activity was found when the temperature was above $70{ }^{\circ} \mathrm{C}$, suggesting that this temperature was a crucial factor affecting the autolysis by thermal denaturation of the endogenous proteinase. Previously it has been shown that the maximum autolytic activity of Indian anchovy, true sardine and goatfish were at $60{ }^{\circ} \mathrm{C}$ (Siringan et al., 2006: Klomklao et al., 2008: Yarnapakdee et al., 2009). Benjakul et al. (2003b) reported that the highest autolysis was observed at $65{ }^{\circ} \mathrm{C}$ for mince from lizardfish muscle. According to autolytic patters (Figure 2), the result indicated that $\mathrm{MHC}$ was degraded greatly at high temperature, presumably caused by the heat-activated proteinase. MHC was better retained at $75{ }^{\circ} \mathrm{C}$. It was postulated that proteinases were denatured to the same extent at high temperatures and lost their activity, which corresponded to them exhibiting the lowest TCA soluble peptides above $70{ }^{\circ} \mathrm{C}$ (Figure 1). Greene and Babbitt (1990) and Visessanguan et al. (2001) also reported that arrowtooth flounder softening was caused by cysteine proteinase with maximum proteolytic activity at $50-60{ }^{\circ} \mathrm{C}$. The autolysis of CFM at the higher temperature than previously reported for other fish was possibly caused by the endogenous proteases in the muscle. It appears that the CFM is more resistant to degradation at the higher temperature than those other fish. This resistance might also be associated with some component of muscle tissue which affected resistance to degradation of enzymes. However, actin in the mince slightly decreased at temperatures higher than $70{ }^{\circ} \mathrm{C}$. Thus, actin might be a substrate for proteolytic enzymes but was less than MHC in clown featherback.

Optimal $\mathrm{pH}$ for clown featherback autolysis observed at $\mathrm{pH} 4$ and 7 was similar to that reported by Yarnapakdee et al. (2009) who noted that heat-activated protease from goatfish (Mulloidichthys martinicus), had optimal activity at pH 4 and 7. Klomklao et al. (2008) reported that autolysis of true sardine is due to a heat-activated proteinase active at $\mathrm{pH} 3.5$ and 8 . Optimal pH values of crude proteinases from Indian anchovy were 3.0 and 8.5-9.5 (Siringan et al., 2006). The results indicated that two major groups of proteases were localized in clown featherback. At very acidic or alkaline $\mathrm{pH}$ levels, the degradation was markedly decreased as evidenced by the lowered TCA-soluble peptide. This might be due to the inactivation of the endogenous proteinase under these conditions. When $\mathrm{pH}$ values are above and below the isoelectric point ( $\mathrm{pI}$ ), a protein or enzyme has a net negative or positive charge, respectively (Vojdani, 1996). The repulsion between charged residues of protein molecules might be associated with conformational changes, leading to the denaturation of enzymes. Due to the different ionic strengths of various buffers used in the $\mathrm{pH}$ profile study, the activity might be affected by such a difference, even to a low extent (Intarasirisawat et al., 2007).

Although low inhibitory activity for all proteinase inhibitors tested (Table 1), pepstatin A showed the highest inhibitory activity which corresponded to the optimum activity at $\mathrm{pH} 4$. Additionally, inhibitory activity of pepstatin A increased as concentration increased from $15.44 \%$ inhibition for $1 \mu \mathrm{M}$ pepstatin A to $20.3 \%$ inhibition for $10 \mu \mathrm{M}$ pepstatin A. MHC was better retained in the presence of $10 \mu \mathrm{M}$ pepstatin A (Figure 5), which was in agreement with the strong effective inhibitory activity of pepstatin A (Table 1). Therefore, it can be 
concluded that the major proteinase found in clown featherback mince was aspartic protease. Other inhibitors also showed inhibition towards autolysis but had less effective inhibitory activity. The results suggested that clown featherback contained a variety of proteases, which had different characteristics. Ishida et al. (1995) reported that neutral serine proteinase, found in muscles of anchovy (Engraulis japonica), exhibited optimum catalytic activity at $\mathrm{pH}$ 7.5. Benjakul et al. (2003a) reported that sarcoplasmic proteinases from bigeye snapper (Priacanthus tayenus) were effectively inhibited by pepstatin A, at $\mathrm{pH} 5.0$, while at $\mathrm{pH} 8.5$ the activity was inhibited by several inhibitors. Klomklao et al. (2008) reported that aspartic protease was the major protease in true sardine. Wang et al. (2011) reported that both cysteine and aspartic protease were responsible for MHC degradation of Atlantic cod while myofibril associated proteinases in lizardfish were both serine and cysteine proteinases (Benjakul et al., 2003b). Yarnapakdee et al. (2009) reported that cysteine proteases and serine proteases were most likely responsible for protein degradation of goatfish.

The major proteins found in CFM were MHC and actin (Figure 6). The result was in accordance to Chaijan et al. (2013) who reported that MHC and actin were the major protein in frigate mackerel and catfish muscle. Additionally, those major protein components also found in sardine, mackerel (Hashimoto et al., 1979), lizard fish (Ohkubo et al., 2004) and bigeye snapper (Benjakul et al., 2003a). In general, tropomyosin and troponin I with molecular weight about $33 \mathrm{kDa}$ and 20-24 kDa, respectively were also consisted in fish muscle (Benjakul et al., 2011). Chaijan et al. (2013) reported that frigate mackerel muscle comprised several protein bands corresponding to $\mathrm{MHC}$, actin, troponin and tropomyosin. The result also showed that proteolytic activity of crude enzyme on CFM at $4{ }^{\circ} \mathrm{C}$ was comparable to that at $25{ }^{\circ} \mathrm{C}$. However, MHC was most susceptible to hydrolysis. Degradation of $\mathrm{MHC}$ and actin were observed when the unit of enzyme from viscera of farmed giant catfish increased (Vannabun et. al., 2014). Furthermore Benjakul et al. (2003a) reported that MHC from bigeye snapper (Priacanthus macracanthus) was hydrolyzed by heat-stable alkaline proteinase isolated from its muscle counterpart, particularly as the incubation time increased.

\section{CONCLUSION}

Autolysis of clown featherback (Chitala ornata) mince occurred at an optimal temperature at $70{ }^{\circ} \mathrm{C}$ with two major autolytic peaks at $\mathrm{pH} 4$ and 7. At physiological $\mathrm{pH}$ (6.73), pepstatin $\mathrm{A}(10 \mu \mathrm{M})$ was most effective in inhibitory activity on autolysis of clown featherback mince. It was therefore presumed that aspartic proteases were most likely a major contributor to protein degradation. Natural actomyosin treated with crude proteolytic enzyme and incubated at $4{ }^{\circ} \mathrm{C}$ and $25{ }^{\circ} \mathrm{C}$ showed similar degradation patterns. Therefore, the endogenous proteases, particularly aspartic proteinases, in clown featherback muscle were judged to be responsible for autolysis at low temperature. 


\section{ACKNOWLEDGEMENTS}

This work was supported by King Mongkut's Institute of Technology Ladkrabang. The authors would also like to thank Professor Dr. Anthony Keith Thompson, Visiting Professor at Faculty of Agro-Industry, King Mongkut's Institute of Technology Ladkrabang for invaluable suggestion and correction.

\section{REFERENCES}

An, H., Weerasinghe, V., Seymour, T.A., and Morrissey, M.T. 1994. Cathepsin degradation of pacific whiting surimi proteins. Journal of Food Science. 59: 1013-1017. https://doi. org/10.1111/j.1365-2621.1994.tb08179.x

Benjakul, S. 2011. Chemical and aquatic animal quality (In Thai). $2^{\text {nd }}$ edition. Bangkok: Odeon Store.

Benjakul, S., Seymour, T.A., Morrissey, M.T., and An, H. 1996. Proteinase in Pacific whiting surimi wash water: identification and characterization. Journal of Food Science. 61: 1165-1170. https://doi.org/10.1111/j.1365-2621.1996.tb10953.x

Benjakul, S., Visessanguan, W., and Leelapongwattana, K. 2003a. Purification and characterization of heat-stable alkaline proteinase from bigeye snapper (Priacanthus macracanthus) muscle. Comparative Biochemistry and Physiology. 134B: 579-591. https://doi.org/10.1016/S1096-4959(02)00290-7

Benjakul, S., Visessanguan, W., and Tueksuban, J. 2003b. Heat-activated proteolysis in lizardfish (Saurida tumbil) muscle. Food Research International. 36: 1021-1028. https://doi.org/10.1016/j.foodres.2003.07.005

Berra T.M. 2001. Freshwater fish distribution. California: University of Chicago.

Chaijan, M., Klomklao, S., and Benjakul, S. 2013. Characterisation of muscles from Frigate mackerel (Auxis thazard) and catfish (Clarias macrocephalus). Food Chemistry. 139: 414-419. https://doi.org/10.1016/j.foodchem.2013.01.111

Department of Fisheries: Clown feather back online [Internet]. [cited 2017 Oct 20]. Available from: http://www.fisheries.go.th/if-lopburi/web2/index.php

Ding, Y.Q., Liu, R., Rong, J.H., Liu, Y.M., Zhao, S.M., and Xiong, S.B. 2012. Rheological behavior of heat-induced actomyosin gels from yellowcheek carp and grass carp. European Food Research and Technology. 235: 245-251. https://oi.org/10.1007/ s00217-012-1750-7

Greene, D.H., and Babbitt, J.K. 1990. Control of muscle softening and protease-parasite interactions in Arrowtooth flounder, Atherestes stomias. Journal of Food Science. 55: 579-580. https://doi.org/10.1111/j.1365-2621.1990.tb06822.x

Hashimoto, K., Watabe, S., Kono, M., and Shiro, K. 1979. Muscle protein composition of sardine and mackerel. Bulletin of the Japanese Society of Scientific Fisheries. 45: 1435-1441.

Intarasirisawat, R., Benjakul, S., Visessanguan, W., Prodpran, T., Tanaka, M., and Howell, N.K. 2007. Autolysis study of bigeye snapper (Priacanthus macracanthus) skin and its effect on gelatin. Food Hydrocolloids. 21: 537-544. https://doi.org/10.1016/j. foodhyd.2006.05.012 
Ishida, M., Sugiyama, N., Sato, M., and Nagayama, F. 1995. Two kinds of neutral serine proteinases in salted muscle of anchovy, Engraulis japonica. Bioscience Biotechnology and Biochemistry. 59: 1107-1112. https://doi.org/10.1271/bbb.59.1107

Kinoshita, M., Toyohara, H., and Shimizu, Y. 1990. Induction of carp muscle multicatalytic proteinase activities by sodium dodecyl sulfate and heating. Comparative Biochemistry and Physiology. 96B: 565-569. https://doi.org/10.1016/0305-0491(90)90057-Z

Klomklao, S., Benjakul, S., Visessanguan, W., Kishimura, H., and Simpson, B.K. 2008. Purification and characterisation of trypsins from the spleen of skipjack tuna (Katsuwonus pelamis). Food Chemistry. 100: 1580-1589. https://doi.org/10.1016/j. foodchem.2006.01.001

Klomklao, S., Kishimura, H., and Benjakul, S. 2008. Endogenous proteinases in true sardine (Sardinops melanostictus). Food Chemistry. 107: 213-220. https://doi.org/10.1016/j. foodchem.2007.08.007

Leammli, U.K. 1970. Cleavage of structure proteins during the assembly of the head of bacteriophage. Nature. 277: 680-685. https://doi.org/10.1038/227680a0

Liu, H., Yin, L., Zhang, N., Li, S., and Ma, C. 2008. Isolation of cathepsin B from the muscle of silver carp (Hypophthalmichthys molitrix) and comparison of cathepsins $\mathrm{B}$ and L actions on surimi gel softening. Food Chemistry. 110: 310-318. https://doi. org/10.1016/j.foodchem.2008.01.068

Lowry, O.H., Rosebrough, N.J., Farr, A.L., and Randall, R.J. 1951. Protein measurement with the Folin phenol reagent. Journal of Biological Chemistry. 193: 265-275.

Morrissey, M.T., Hartley, P.S., and An, H. 1995. Proteolytic activity in Pacific whiting and effects of surimi processing. Journal of Aquatic Food Product Technology. 4: 5-18. https://doi.org/10.1300/J030v04n04_02

Nalinanon, S., Benjakul, S., and Kishimura, H. 2010. Biochemical properties of pepsinogen and pepsin from the stomach of albacore tuna (Thunnus alalunga). Food Chemistry. 121: 49-55. https://doi.org/10.1016/j.foodchem.2009.11.089

Ohkubo, M., Miyagawa, K., Osatomi, K., Hara, K., Nozaki, Y., and Ishihara, T. 2004. Purification and characterization of myofibril-bound serine protease from lizard fish (Saurida undosquamis) muscle. Comparative Biochemistry and Physiology. 137B: 139-150. https://doi.org/10.1016/j.cbpc.2003.10.015

Saeki, H., Iseya, Z., Sugiura, S., and Seki, N. 1995. Gel forming characteristic of frozen surimi from chum salmon in the presence of protease inhibitor. Journal of Food Science. 60: 917-921. https://doi.org/10.1111/j.1365-2621.1995.tb06261.x

Siringan, P., Raksakulthai, N., and Yongsawatdigul, J. 2006. Autolytic activity and biochemical characteristics of endogenous proteinases in Indian anchovy (Stolephorus indicus). Food Chemistry. 98: 678-684. https://doi.org/10.1016/j.foodchem.2005.06.032

Sriket, C. 2014. Proteases in fish and shellfish: Role on muscle softening and prevention. International Food Research. 21: 433-445.

Toyohara, H., and Shimizu, Y. 1988. Relation between the modori phenomenon and myosin heavy chain breakdown in threadfin bream gel. Agricultural and Biological Chemistry. 52: 255-257. 
Toyohara, H., Sakata, T., Yamashita, K., Kinoshita, M., and Shimizu, Y. 1990. Degradation of Oval-Filefish meat gel caused by myofibrillar proteinases(s). Journal of Food Science. 55: 364-368. https://doi.org/10.1111/j.1365-2621.1990.tb06764.x

Uk-katawewat, S. 2004. Freshwater fish volume 1 (In Thai). First printing. Bangkok: Business organization of the office of the Welfare Promotion Commission for Teacher and Educational Personnel (Kurusapa Bussiness Organization).

Vannabun, A., Ketnawa, S., Phongthai, S., Benjakul, S., and Rawdkuen, S. 2014. Characterization of acid and alkaline proteases from viscera of farmed giant catfish. Food Bioscience. 6: 9-16. https://doi.org/10.1016/j.fbio.2014.01.001

Visessanguan, W., Benjakul, S., and An, H. 2003. Purification and characterization of cathepsin $\mathrm{L}$ in arrowtooth flounder (Atheresthes stomias) muscle. Comparative Biochemistry and Physiology. 134B: 477-487. https://doi.org/10.1016/S1096-4959(02)00293-2

Visessanguan, W., Menino, A.R., Kim, S.M., and An, H. 2001. Cathepsin L: a predominant heat-activated proteinase in arrowtooth flounder muscle. Journal of Agricultural and Food Chemistry. 49: 2633-2640. https://doi.org/10.1021/jf010304k

Vojdani, F. 1996. Solubility. In: Hall, G.M. (Ed.). Methods of testing protein functionality (11-60). London, Great Britain: St. Edmundsbury Press.

Wang, P.A., Vang, B., Pedersen, A.M., Martinez, I., and Olsen, R.L. 2011. Post-mortem degradation of myosin heavy chain in intact fish muscle: Effects of $\mathrm{pH}$ and enzyme inhibitors. Food Chemistry. 124: 1090-1095. https://doi.org/10.1016/j. foodchem.2010.07.093

Wu, G.P., Chen, S.H., Liu, G.M., Yoshida, A., Zhang, L.J., Su, W.J., and Cao, M.J. 2010. Purification and characterization of a collagenolytic serine proteinase from the skeletal muscle of red sea bream (Pagrus major). Comparative Biochemistry and Physiology. 155B: 281-287. https://doi.org/10.1016/j.cbpb.2009.11.014

Yarnpakdee, S., Benjakul, S., Visessanguan, W., and Kijroongrjana, K. 2009. Autolysis of goatfish (Mulloidichthys martinicus) mince: Characterisation and effect of washing and skin inclusion. Food Chemistry. 114: 1339-1344. https://doi.org/10.1016/j. foodchem.2008.11.014 